\title{
Cartographic visualization of Jewish heritage in cross-border tourist project Shtetl Routes (Poland, Belarus, Ukraine)*
}

\begin{abstract}
The aim of the author of this article is to present cartographic visualizations designed for an international tourist project Shtetl Routes. The methodology consists of the study of early topographic maps, field studies, GIS analyses and 3D modelling. 63 town maps, 15 virtual mock-ups and a large thematic map have been developed as results. Multiple methodological problems are discussed. Cartographic products designed for the project have already been published or will be published in the near future.
\end{abstract}

Keywords: cartographic visualization, Historical GIS, 3D, Shtetl Routes, Jewish heritage

\section{Introduction}

During the World War II, German Nazis held a near total extermination of Jewish community of eastern interwar Poland (1918-1939). Shtet Routes: vestiges of Jewish cultural heritage in cross-border tourism is an international project that aims to create a supra-regional tourist route based on the Jewish cultural heritage of border regions of Poland, Belarus and Ukraine (shtetlroutes.eu). The project included three cartographic objectives: designing town plans for the guidebook, designing large tourist map and developing virtual 3D mock-ups of selected towns. The mapping of preserved traces of Jewish culture as well as the most important non-existent objects of their cultural heritage was a very difficult issue. The creation of cartographic products for tourists required combining enormous documentation that had been gathered during interdisciplinary research. Early maps, Geographic Information Systems (GIS) and cartographic visualization played an important - if not crucial - role in the project. Following

\footnotetext{
* The term "shtetl" (yid. noun, singular) stands for small town with large Jewish population, which existed in Central and Eastern Europe before the Holocaust. The article is an extension of the analysis presented at the 39th Polish Cartographic Conference, Zwierzyniec 2016.
}

the spatial turn in humanities (A. Knowles 2002, D. Bodenhamer et al. 2010), cartographic methods of research and GIS tools were present at every stage of the project: starting as a base material for field study, setting domain for the collection of data and finishing as a complete set of products for tourists.

\section{Methodology, acquisition of data}

The main idea of the Shtetl Routes project was to use the remains of Jewish cultural heritage to create the tourist product that would promote the unique beauty of small towns of eastern Poland, western Belarus and western Ukraine. To accomplish ambitiously stated goal at the highest standards it was required to gather an international team of specialists and to use an interdisciplinary approach. At the beginning a list of 63 destinations of Shtet Routes (tab. 1) was selected: 20 towns from Belarus, 21 from Poland and 22 from Ukraine. Among them 15 were selected for 3D modelling (shtetlroutes.eu, poligonstudio.pl). The criteria of selection were rather subjective: the main points were if any extraordinary examples of Jewish architecture were preserved and if towns were small - generally, population should be fewer than 50,000 . Experts concluded that 
Tab. 1. List of towns selected for Shtetl Routes. Towns with thicked names were selected for 3D modelling

\begin{tabular}{|l|l|l|}
\hline \multicolumn{1}{|c|}{ Belarus } & \multicolumn{1}{c|}{ Poland } & \multicolumn{1}{c|}{ Ukraine } \\
\hline Ashmyany & Biłgoraj & Belz \\
\hline Davyd-Haradok & Dukla & Berezne \\
\hline Dzyatlava & Izbica & Bolekhiv \\
\hline Haradzishcha & $\begin{array}{l}\text { Józefów } \\
\text { Roztoczański }\end{array}$ & Brody \\
\hline Indura & $\begin{array}{l}\text { Kazimierz } \\
\text { Dolny }\end{array}$ & Buchach \\
\hline Iwye & Knyszyn & Busk \\
\hline Kobryn & Kock & Chortkiv \\
\hline Lunna & Krynki & Delatyn \\
\hline Mir & Lesko & Drohobych \\
\hline Motal & Łancut & Dubno \\
\hline Navahrudak & Łęczna & Halych \\
\hline Ostryna & $\begin{array}{l}\text { Międzyrzec } \\
\text { Podlaski }\end{array}$ & Khust \\
\hline Pinsk & Orla & Korets \\
\hline Pruzhany & Rymanów & Kosiv \\
\hline Radun & Sejny & Kovel \\
\hline Ruzhany & Siemiatycze & Kremenets \\
\hline Slonim & Szczebrzeszyn & Liuboml \\
\hline Stolin & Tykocin & Ostroh \\
\hline Volozhyn & Wielkie Oczy & Pidhaitsi \\
\hline Zheludok & Wojsławice & Rohatyn \\
\hline & Włodawa & $\begin{array}{l}\text { Volodymyr- } \\
\text {-Volynsky }\end{array}$ \\
\hline Zhovkva \\
\hline
\end{tabular}

there is no point in promoting big cities (such as Lublin or Lviv) or internationally recognized landmarks (such as Zamość).

At first stage of the project cartographic research was focused on gathering archival maps from period 1900-1940 (igrek.amzp.pl, mapywig.org). The research resulted in obtaining digital copies of 115 early topographic maps at scales from 1:25,000 up to $1: 100,000$ (tab. 2). Topographic situation presented on plans and maps varied chronologically (P. Cebrykow 2015, A. Czerny 2015, J. Kuna 2014). Among topographic maps at the scale of 1:25,000 1 German map and 17 Polish maps were appropriate for Shtetl Routes, 3 Polish maps and all Soviet maps at this scale were out of date. Soviet Red Army's maps 1:42,000 and 1:50,000 and Austro-Hungarian Spezialkarte 1:75,000 were also outdated. All Polish tactical maps at the scale 1:100,000 were considered adequate.

At second stage, maps were rectified in GIS and compared with current spatial data - satellite images, ortophotomaps, maps and plans (T. Panecki 2014, J. Kuna 2015a, B. Szady 2008). Digitalization of features connected to Jewish heritage (synagogues, cemeteries, etc.) resulted in creating a database of possible locations of historic sites and monuments. The database was converted to $\mathrm{KML}$ format and shared via Google Maps - researchers working in field identified points of interests (POI), corrected location (address, GPS coordinates), updated the status of monuments, created documentation (photo), described characteristics and filled the database with other places that were considered "worth seeing". Collecting of the data in field required no sophisticated technology as popular smartphone applications seemed sufficient. The majority of field researchers used on-line version of Google Maps and Open Street Map (which sometimes had more detailed layers, especially in Belarus). However, few researchers admitted that traditional equipment (printed map, notebook and pen) was the most dependable. During the field research, a large number of features, objects and sites was marked in the project's Google Maps. Updated layers were reconverted into GIS database, all records were catalogued

Tab. 2. List of archival topographic maps gathered for cartographic research

\begin{tabular}{|l|c|c|c|}
\hline \multicolumn{1}{|c|}{ Map } & Scale & Sheets & Situation \\
\hline Messtischblätter & $1: 25,000$ & 1 & 1940 \\
\hline Soviet Red Army (reprints of Half-Verst maps) & $1: 25,000$ & 6 & $1885-1904$ \\
\hline WIG detailed map & $1: 25,000$ & 20 & $1892-1937$ \\
\hline Soviet Red Army (reprints of One-Verst maps) & $1: 42,000$ & 2 & $1893-1896$ \\
\hline Soviet Red Army (redrafts of One-Verst maps) & $1: 50,000$ & 3 & $1888-1891$ \\
\hline Spezialkarte & $1: 75,000$ & 3 & $1874-1914$ \\
\hline WIG tactical map & $1: 100,000$ & 79 & $1922-1938$ \\
\hline
\end{tabular}




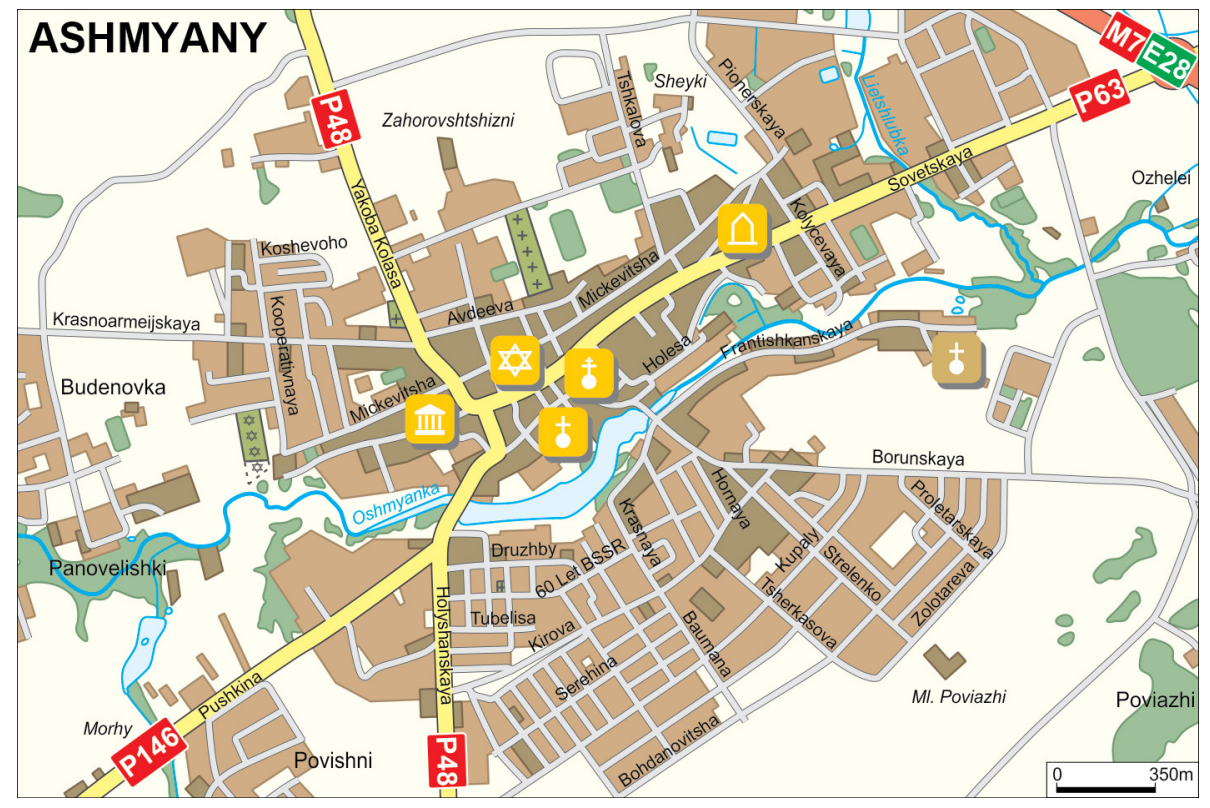

Fig. 1. Ashmyany (Belarus) 1:35,000 - town map designed for the Shtetl Routes guidebook (sample)

in 15 categories: 5 categories referred strictly to Jewish heritage, 5 categories referred to sacral objects of Christianity (Latin or Orthodox) and Islam, other categories included secular features. Preservation status was coded with Boolean: 1 - "preserved", 0 - "not preserved". Comments like "active", "closed", "rebuild", "in ruins", "changed usage" were added to records with "true" values. GIS database served as a foundation for designing maps (J. Kuna 2015a). Along with the development of the project, the idea of designing online, interactive map was mentioned. Unfortunately, it had to be postponed due to the rigid budget.

\section{Cartographic products}

As three types of cartographic visualization have been developed for the project, different problems occurred. Methodological questions, solutions and workflow are described below, along with each type of the cartographic product.

\subsection{Town maps}

The most fundamental methodological questions appeared before the design of town maps had started. The only outline for the guidebook was the size of a single page $(16 \mathrm{~cm} \times 23.5 \mathrm{~cm})$. GIS analyses revealed that selected towns differ in many characteristics: number of POls, area covered by thematic features, complexity of urban arrangement, etc, therefore there was no possibility to draw all maps at equal scale. It was decided that dimensions of each map should be constant: rectangular, $12 \mathrm{~cm} \times 8 \mathrm{~cm}$, horizontal or vertical - depending on the range of presented area. Thus, scales of town maps vary from $1: 7,500$ to $1: 40,000$ resulting in different level of generalization and all further consequences (M.-J. Kraak, F. Ormeling 2010, J. Kuna 2015a).

Another methodological problem occurred when the base map was considered. It seemed impossible to decide whether the maps should present current or historical situation (B. Szady 2008). Obviously, current situation is necessary for map's user to locate sites and monuments in present space of the town. However, thematic layer of designed maps mostly consists of historic features, hence presenting interwar situation has a logic explanation as well. The aim of the Shtetl Routes project is to invite tourists to participate in a journey that is both physical and mental. The authors decided 


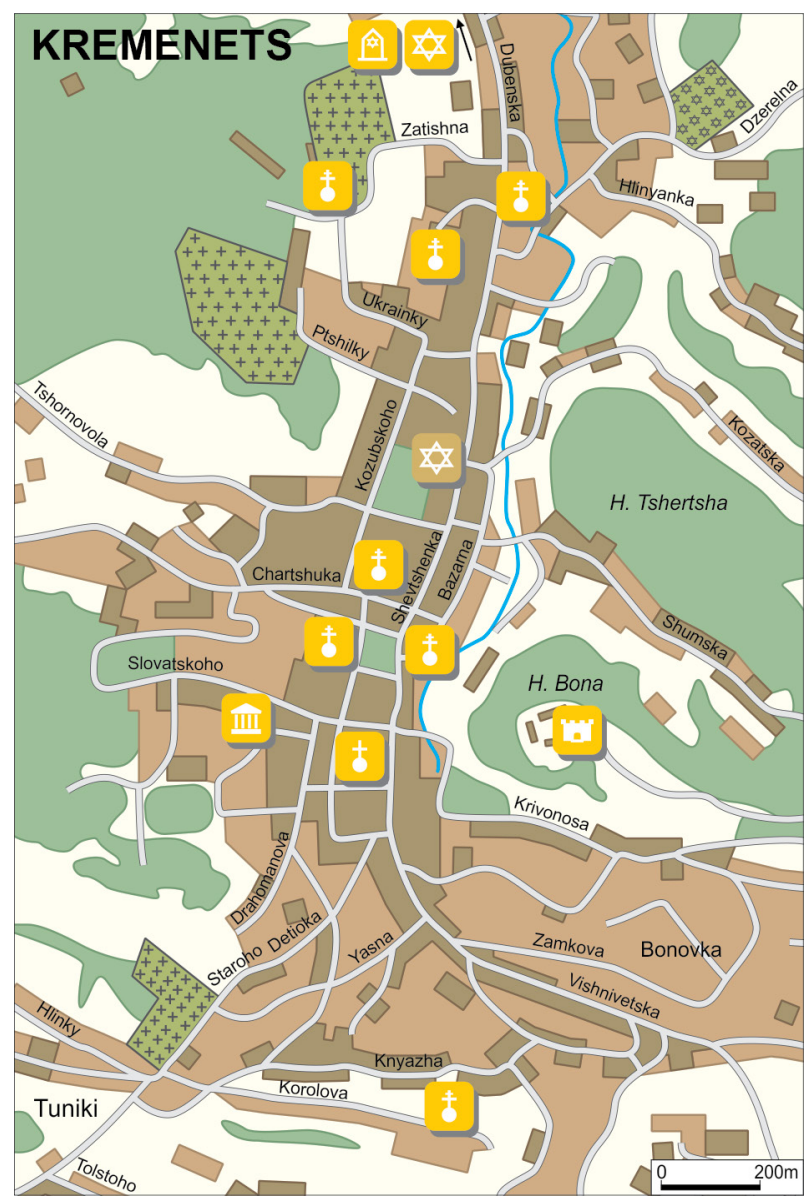

Fig. 2. Kremenets (Ukraine) 1:20,000 - town map designed for the Shtetl Routes guidebook (sample)

to choose compromising solution. While all other features are drawn up to date, build-up area is shown at two stages: pre-WW II and current (fig. 1, fig. 2). Cartographic presentation of change adds another dimension (time) to these primarily simple maps, giving them a new, deeper meaning (M.-J. Kraak, F. Ormeling 2010, B. Szady 2008). Despite the fact that this methodological solution is not innovatory itself, there are only a few similar cartographic products where the presentation of dynamics can be encountered (M. Meksuła 2001).

The design of cartographic symbols was also problematic. Graphic representation of database features had to be simple, unambiguous and neat. The accordance with the isomorphism rule and the thematic resemblance between features were desired (M.-J. Kraak, F. Ormeling 2010). Shtetl Routes's point symbols were designed in the combined manner. The outer geometrical figure $(5 \mathrm{~mm} \times 5 \mathrm{~mm})$ is common for all signs. Signatures are distinguished by inner shapes, which are: simplified depictions of the reality or abstract symbols that would easily associate with the reality. The colour of outer field divides signatures into two categories depending on preservation status (fig. 3). Cartographic symbolization of roads encountered serious problem in terms of comparability between three countries. Contrary to Poland or Ukraine, in Belarus the system of administrative categorization had no reference with qualitative attributes. To obtain corresponding values, nominal parameters had to be 


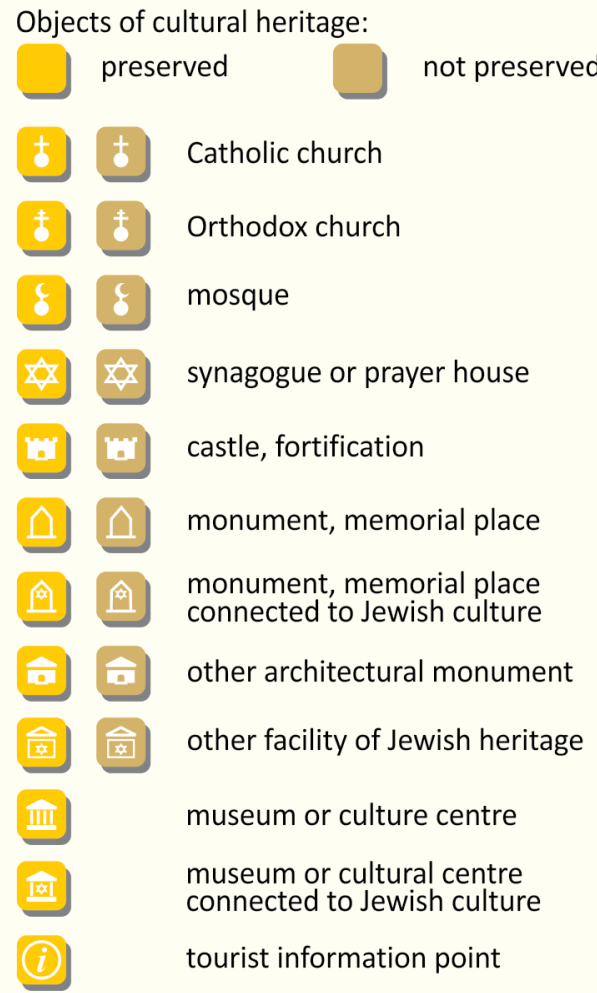

Cemeteries:

$\begin{array}{llll}+_{+}^{+} \text {Christian } & { }^{C} c^{c} & \text { Muslim } \\ { }_{+\infty} \text { Jewish } & & \text { not preserved }\end{array}$

Buildings and build-up areas:

before WW II

after WW II

Fig. 3. The common legend for all 63 town maps in the Shtetl Routes guidebook (thematic features only)

changed. Experience of field researchers was the key. With such a diversity of signatures the legend was needed, but there was no possibility to place the legend within limited size of maps. Expecting random placement of maps throughout the guidebook, authors came with an idea that printing legend at an external part of the cover (that would fold in and out) would be useful.

Shtetl Routes project is targeted on international tourists. While the guidebook is written in four language versions (English, Belarusian,
Polish and Ukrainian), designing versions of maps separately for every language turned out very problematic. Due to different lengths of words endless changes of text's placement reminded cartographic nightmare. Small maps of towns did not allow to use combined, multilingual texts (doubled, tripled or quadrupled). Therefore it was decided to use one common version of maps, with English transcription (shtetlroutes.eu).

\subsection{Three dimensional mock-ups}

Modelling of virtual mock-ups (maquettes) requires base maps at very high level of detail, so that the location and dimensions of single building can be precisely measured (J. Kuna 2015b). Among collected topographic maps only a few maps 1:25,000 could meet such requirements and only 2 depicted towns that were selected for modelling. Another query carried in national archives was focused on town plans and cadastral plans. It resulted in collecting 16 different maps that were presenting selected towns in different periods (tab. 3 ). Timeliness of 8 archival maps was proper for the Shtetl Routes project. With lack of adjacent sources for 7 other towns, modellers had to be satisfied with earlier or newer plans (geshergalicia.org).

Mock-ups are provided by professional modellers - mainly Poligon Studio from Lublin (poligonstudio.pl). Minority of mock-ups were modelled straight on raster images of archival maps. For majority realistic phototextures had been designed. In most cases surface under buildings is flat, whereas terrain outside build-up area is varied. It may lead to the conclusion that the terrain models used in mock-ups are hand-made.

Models of buildings stand at a very high level of detail such as Open Geospatial Consortium CityGML Level of Detail 2 and 3. OGC CityGML is an internationally used standard of 3D modelling. LoD 2 refers to models of buildings with photographic textures, proper roof types, adjacent cubature and all details that exceed $1 \mathrm{~m}$. LoD 2 models are used to present less important buildings that would fill the background of mock-ups. LoD 3 refers to models of buildings with photographic textures, precise geometry of roofs and every outer detail that exceed $0.5 \mathrm{~m}$. 
Tab. 3. List of archival maps and plans used for 3D modelling

\begin{tabular}{|l|l|c|c|}
\hline \multicolumn{1}{|c|}{ Town } & \multicolumn{1}{c|}{ Map } & Year & Scale \\
\hline \multirow{2}{*}{ Berezne } & Sketch plan of Berezne (pol.) & 1926 & $1: 2,500$ \\
\hline \multirow{2}{*}{ Indura } & Current land use map of the county town Biłgoraj (rus.) & 1902 & $1: 5,000$ \\
\cline { 2 - 4 } & Map of Biłgoraj City (ger.) & 1918 & $1: 5,000$ \\
\hline \multirow{2}{*}{ Knyszyn } & WIG tactical map, sheet: P35 S38 (pol.) & 1926 & $1: 100,000$ \\
\hline \multirow{2}{*}{ Luboml } & Site map of Knyszyn (pol.) & 1947 & $1: 1,000$ \\
\hline \multirow{2}{*}{ Mir } & Locations near the town of Kock (rus.) & 1814 & $1: 20,320$ \\
\cline { 2 - 4 } & GUGiK topographic map, sheet: 125.244 (pol.) & 1970 s & $1: 10,000$ \\
\hline \multirow{3}{*}{ Navahrudak } & Copy map of the county town Luboml (pol.) & 1926 & $1: 5,000$ \\
\hline \multirow{2}{*}{ Ostroh } & Detailed map of the Mir's town squares (pol.) & 1831 & $1: 1,840$ \\
\cline { 2 - 4 } & WIG detailed map, sheet: P35 S43 A (pol.) & 1934 & $1: 25,000$ \\
\hline \multirow{2}{*}{ Pidhaitsi } & Map of the voivodship city Navahrudak (pol.) & 1927 & unknown \\
\cline { 2 - 4 } & Map of the city of Navahrudak (pol.) & 1931 & $1: 5,000$ \\
\cline { 2 - 4 } & City map of Navahrudak (pol.) & 1935 & $1: 12,500$ \\
\hline Ruzhany & Jewish memorial map of Ostroh (hebr.) & 1930 s & unknown \\
\hline Wielkie Oczy & Cadastral map of Pidhaitsi and surrounding settlements (pol.) & 1846 & unknown \\
\cline { 2 - 4 } & Cadastral map of Pidhaitsi (pol.) & 1939 & $1: 5,000$ \\
\hline Wojsławice & WIG detailed map, sheet: P37 S40 D (pol.) & 1932 & $1: 25,000$ \\
\hline Zheludok & Cadastral map of Wielkie Oczy (pol.) & 1910 & $1: 1,000$ \\
\hline \multirow{2}{*}{ Zhovkva } & General map of Wojsławice estate (pol.) & 1833 & unknown \\
\hline & WIG tactical map, sheet: P34 S40 (pol.) & 1929 & $1: 100,000$ \\
\hline & Map of the city of Zhovkva and its castle granting (ger.) & 19 th cent. & $1: 4,900$ \\
\cline { 2 - 4 } & Sketch plan of Zhovkva (pol.) & 19 th cent. & $1: 2,880$ \\
\hline
\end{tabular}

Maps and plans names translated on the basis of: Kuncewicz A., 1929: Plany przeglądowe miast polskich and Lewandowska M., Stelmach M., 1996: Plany miast w polskich archiwach państwowych - katalog

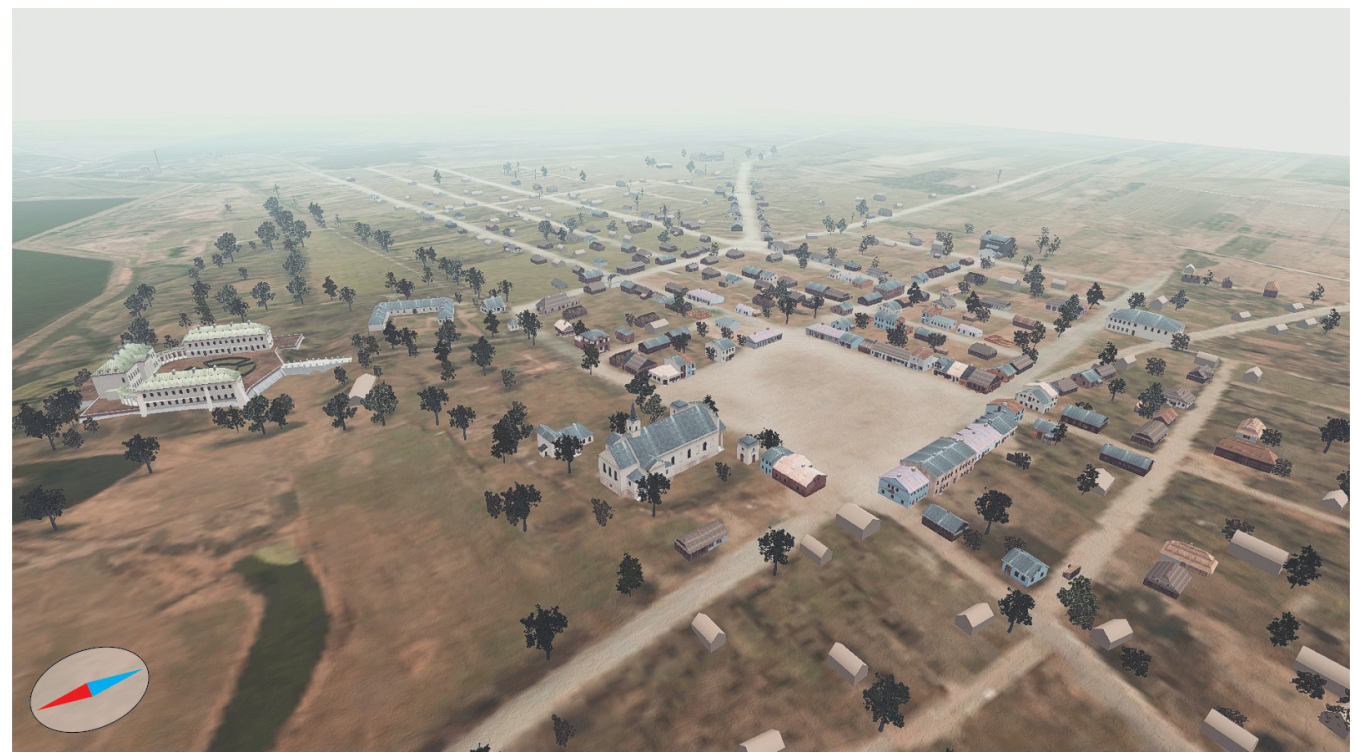

Fig. 4. Kock 1930s (Poland) - Shtetl Routes 3D mock-up (sample) (source: poligonstudio.pl) 
LoD 3 models are used to present unique buildings. The combination of LoD 2 and LoD 3 buildings placed on large-scale map or textured Digital Terrain Model filled with 3D models of trees created attractive mock-ups (fig. 4). The addition of effects of sunlight, shadows, fog, cloudy sky and (in some cases) even shiny water with reflections of objects in model teasers rendering, makes Shtetl Routes mockups a digital masterpiece (fig. 5). to Suceava (S) and from Łomża (W) to Kamianets-Podilskyi (E). The generalization is similar to the International Map of the World $1: 1,000,000$ but the level of detail is higher especially in matter of towns and road network (fig. 6). The selection of cartographic projection for Shtetl Routes map was problematic. To reduce distortions, authors decided to use $3^{\circ}$ Gauss-Krüger projection with central meridian at $25^{\circ} \mathrm{E}$. Due to an irregular distribution of

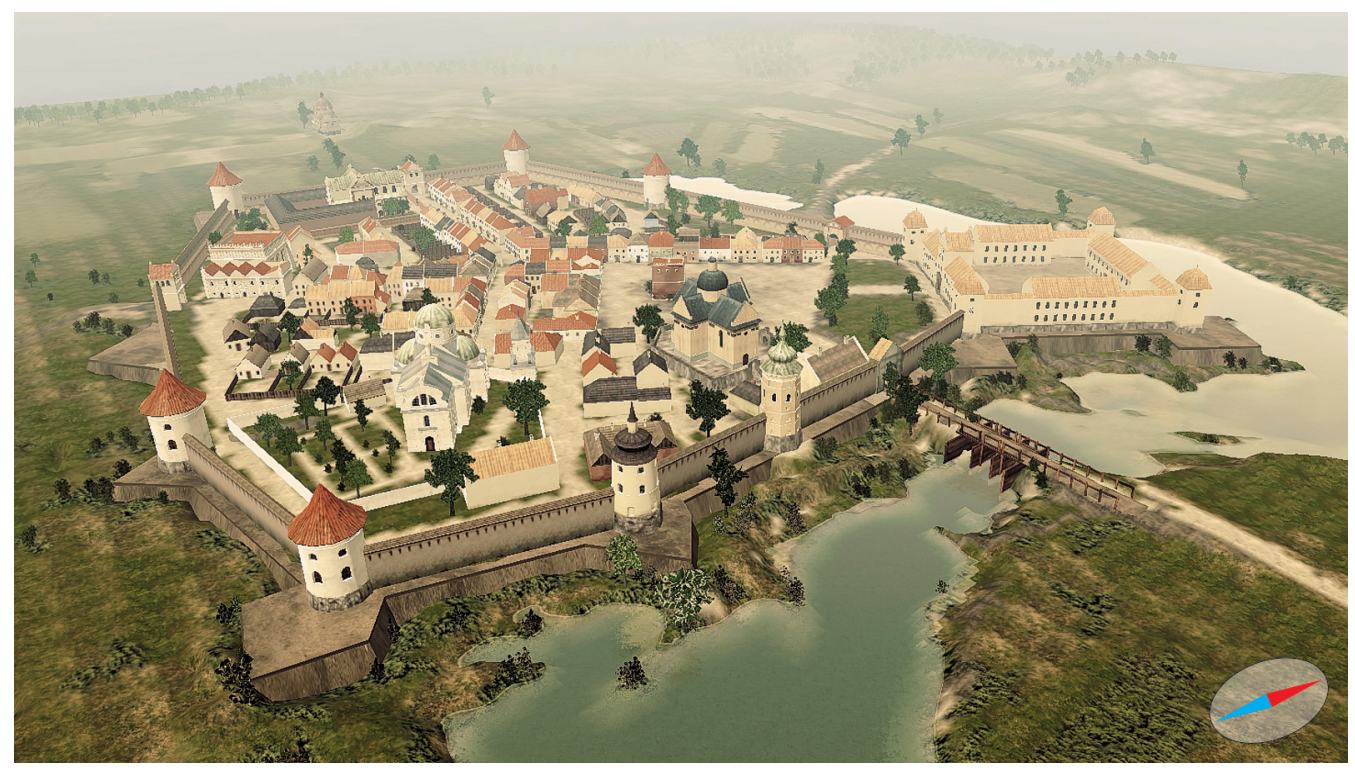

Fig. 5. Zhovkva XVIII (Ukraine) - Shtetl Routes 3D mock-up (sample) (source: poligonstudio.pl)

Current experiences with the online, interactive application "Guidebooks 2.0." (teatrnn.pl/ przewodniki) are rather positive. The technology allows to fly through the mock-up, clicking on particular object triggers popup window with further information about the object. Yet, it is difficult to predict how the technology would behave with such detailed mock-ups.

\subsection{The tourist map}

The thematic map of Shtetl Routes has been designed at scale of 1:900,000 (J. Kuna et al. 2016). Vertical A1 sheet covers the area of approximately $330,000 \mathrm{~km}^{2}$ : from Vilnius (N) the destination towns (SSW-NNE shift) the base map was rotated by $12^{\circ}$ clockwise to reduce the size of a sheet.

The design of cartographic symbols was challenging as it was supposed to correspond with the system used in the guidebook. Except for Jewish cemeteries, the thematic layer was limited to preserved features connected to Jewish heritage. New categories have been added (e. g. active synagogue, German Nazi concentration camps and extermination camps). Signatures are smaller than in the guidebook $(3 \mathrm{~mm} \times 3 \mathrm{~mm})$ and use more contrasting colours (gold and black instead of gold and white).

The number of mapped cities and towns exceeds 5,000 (tab. 4). Except for 63 main Shtet 


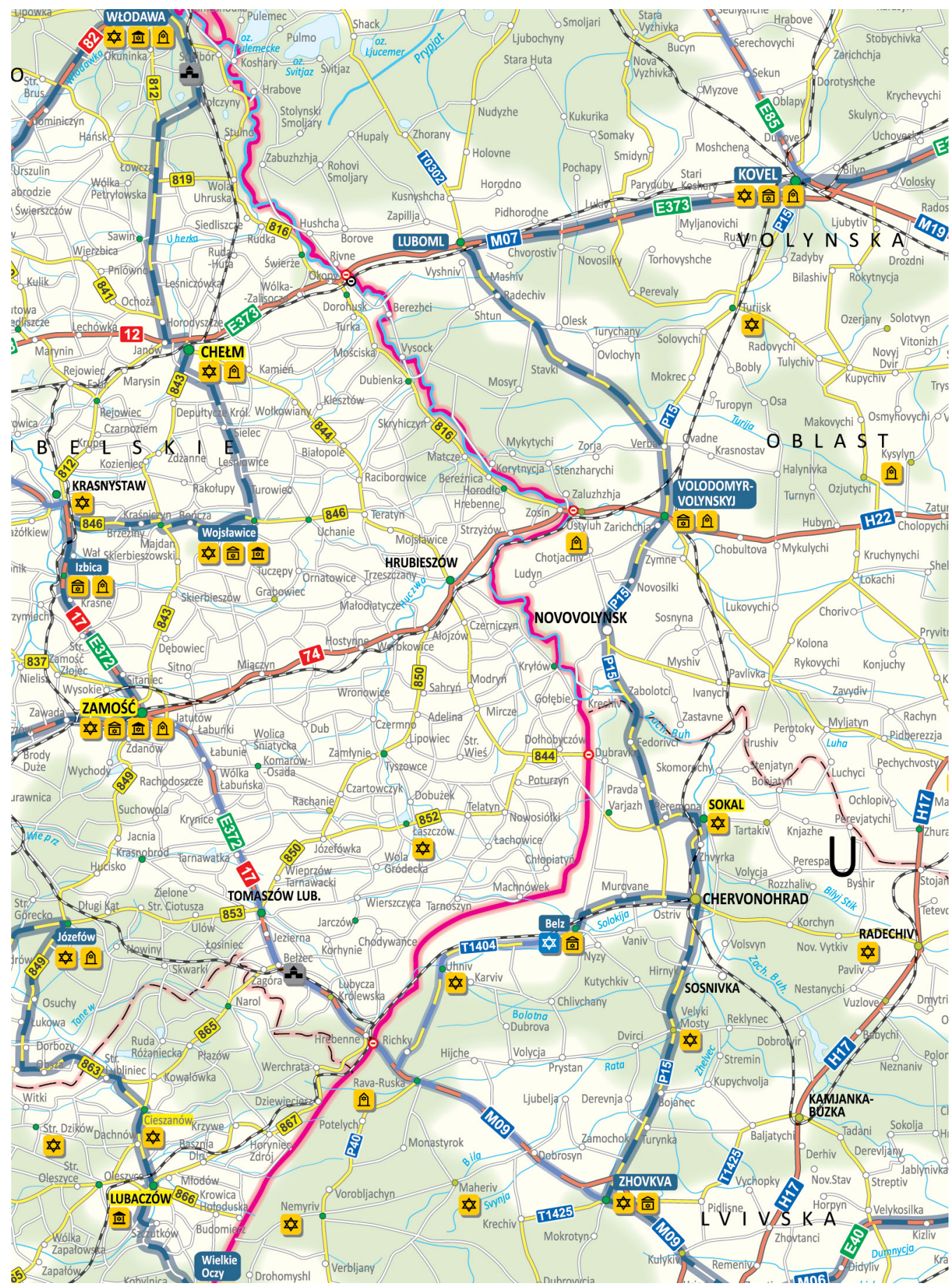

Fig. 6. Shtetl Routes - part of tourist map 1:900,000 (source: J. Kuna et al.: Shtetl Routes. Vestiges of Jewish cultural heritage in cross-border tourism, Lublin 2016) 
Routes towns, 68 other towns have been highlighted as "with important objects of Jewish heritage". The authors mapped, what is believed to be, a complete database of 538 towns with preserved Jewish cemeteries and 127 towns where Jewish cemeteries historically existed but are not preserved. In 237 towns preserved buildings of former synagogues have been marked (23 still active). 69 monuments or memorial places and 29 museums and cultural centres connected to Jewish heritage have been marked in selected towns as well as 58 towns with other facilities of Jewish heritage. 2 signatures of German Nazi concentration camps and 6 signatures of German Nazi extermination camps close the list of thematic features.

\section{Discussion}

Creating cartographic products on the basis of archival maps and historical data is burdened with methodological hesitance and may encounter awkward questions. One can ask why these towns were selected and others weren't, why map " $X$ " was chosen to compare with map " $Y$ " instead of map " $Z$ ", why town "A" is shown at year " $x x x x$ " and town " $B$ " at year "yyyy". Some decisions are always to be made. Instead of asking "why" the role of a cartographer in Shtetl Routes project was to answer "how" to get things done.

The list of towns (tab. 1) was selected by a team of recognized authorities that specialize in history of 20th century, history of Jews, and history of art. Cartographic research included the study of 20th century topographic maps starting from maps 1:25,000 (Messtischblätter, Red Army, WIG) and ending on maps 1:100,000 (WIG). Query resulted in collecting detailed 1:25,000 maps of 15 compete towns and 2 more towns fragmentary (tab. 2). Soviet maps $1: 42,000$ and $1: 50,000$ added depictions of 3 towns. Polish maps $1: 100,000$ by WIG provided complete image of all 63 towns - some sheets were reprinted and rescaled from Spezialkarte 1:75,000 hence finding antecedent maps it seemed proper (P. Cebrykow 2015, A. Czerny 2015). Design of all 63 town maps was done by confronting the most accurate archival topographic maps with current topographic maps, town maps and satellite images. In $1 / 3$ of causes, comparison of maps and data
Tab. 4. Amount of thematic features on Shtetl Routes tourist map 1:900,000

\begin{tabular}{|l|r|}
\hline \multicolumn{1}{|c|}{ Object type } & Amount \\
\hline Big city (areal feature) & 42 \\
\hline Small city & 226 \\
\hline Town or big village & 4989 \\
\hline Shtetl Routes city or town & 63 \\
\hline $\begin{array}{l}\text { Other city or town with important } \\
\text { objects of Jewish heritage }\end{array}$ & 68 \\
\hline $\begin{array}{l}\text { Town with preserved or partially } \\
\text { preserved Jewish cemetery }\end{array}$ & 538 \\
\hline Town with not preserved Jewish cemetery & 127 \\
\hline Active synagogue or prayer house & 23 \\
\hline Preserved building of former synagogue & 214 \\
\hline $\begin{array}{l}\text { Museum or cultural centre connected } \\
\text { to Jewish culture }\end{array}$ & 29 \\
\hline Monument or memorial place (selected) & 69 \\
\hline Other facility of Jewish heritage (selected) & 58 \\
\hline German Nazi concentration camp & 2 \\
\hline German Nazi extermination camp & 6 \\
\hline
\end{tabular}

at similar level of detail resulted in designing of output map at similar scale (figs. 1 and 2). For $2 / 3$ of towns it was a comparison of Polish map 1:100,000 from the 20th century 1920s and 1930s with much more precise current data. The question about reliability of outcome based on such a comparison must occur in the consequence (J. Kuna 2014, J. Kuna 2015a). Thankfully, detail on WIG tactical map is more comparable with generalization on modern maps $1: 50,000$ rather than $1: 100,000$ and therefore the accuracy of output maps is convincing enough (P. Cebrykow 2015, J. Kuna 2014).

Modelling of virtual mock-ups required more detailed base maps (tab. 3) - only 2 topographic maps $1: 25,000$ were used as a basis. For 11 towns 18 other large-scale maps and plans were used. Among them, for 4 more towns interwar plans were found, for 7 other towns only earlier plans were preserved (e.g. XIX century cadastral plans). 2 towns had neither large-scale topographic maps nor town plans, thus WIG tactical maps were used. It may lead to a question about the timeliness of what was supposed to be an interwar period mock-ups. 7 out of 15 mock-ups have been designed for 1920s and 1930s (fig. 4), 2 mock-ups present towns in 1910s, 5 mock-ups present earlier situation (19th, 18th and 17th century). Only 
one mock-up presents latter stage - 1940s. It shows that the methodology of modelling was not equal. The quality of source maps was an important factor, however few base maps have been successfully compiled of two or more maps. There is no methodical explanation why 3 towns were modelled to present a pre-industrial stage. The decision in this matter was not within the author's competence. Despite occasional historical inaccuracy, 3D mock-ups created for Shtetl Routes stand at world-class level (fig. 5).

\section{Summary}

In Shtetl Routes project, cartographic research and cartographic visualization encountered multiple methodological and technical challenges. The creation of the unified system of large-scale town maps for the guidebook was based on a diverse set of data. Cartographic work required organized workflow. GIS tools were very helpful at the stages of gathering, adjusting and analysing data (B. Szady 2008, J. Kuna 2015a). Each map's projection, scale and range were set in GIS. Cartographic editing (symbology, colours, effects) was done in classic vector graphics, however. Preparations for the design of small-scale tourist map was also done in GIS, although editing (which was much more demanding, obviously) was done in vector and raster graphics (fig. 6). Conversions between GIS, vector graphics

\section{Literature}

Bodenhamer D.J., Corrigan J., Harris T.M., 2010, The Spatial Humanities: GIS and the future of humanities scholarship. Bloomington: Indiana University Press.

Cebrykow P., 2015, Dawne mapy topograficzne Lubelszczyzny jako źródła informacji w badaniach historyczno-geograficznych. In: A. Czerny, ed., Dawne mapy topograficzne w badaniach geograficzno-historycznych. Lublin: Wydawnictwo UMCS, pp. 85-102 (http://phavi.umcs.pl/at/attachments/2016/0708/103742-czerny-dawne-mapy-07-07-low-res.pdf).

Czerny A., 2015, Powstanie i etapy rozwoju map topograficznych do końca XIX wieku. In: A. Czerny, ed., Dawne mapy topograficzne $w$ badaniach geograficzno-historycznych. Lublin: Wydawnictwo UMCS, pp. 85-102 (http://phavi.umcs.pl/at/at- and raster graphics allowed to benefit from each format's advantages and fill its imperfections. Regrettably, apart from providing few cartographic basis the author did not participate in 3D modelling.

The cost of the whole Shtetl Routes project was estimated at $450,000 €$ (timesofisrael.com, haaertz.com). Cartographic research and cartographic visualization took up an insignificant amount of funds (except 3D modelling which I assume, took a vast majority). It is puzzling how tiny work (in value) can play a fundamental role in the whole project.

\section{Credits}

The Shtetl Routes project lead by Emil Majuk ("Grodzka Gate - NN Theatre" Centre Lublin, Poland) is done in cooperation with Yanka Kupala State University of Grodno (Hrodna, Belarus), Navahrudak Museum of History and Regional Studies (Navahrudak, Belarus), Centre for Social and Business Initiatives in Yaremche (Yaremche, Ukraine), Rivne Marketing Research Centre (Rivne, Ukraine). The project is co-financed by the European Union under European Neighbourhood and Partnership Instrument Programme for Cross-Border Co-operation Poland-Belarus-Ukraine 2007-2013, grant no. PBU/0594/11. The author is thankful for an invitation and opportunity to participate in the project.

tachments/2016/0708/103742-czerny-dawne-mapy-07-07-low-res.pdf).

Knowles A. K., 2002, Past time, past place: GIS for history. Redlands: ESRI Press.

Kraak M.-J., Ormeling F., 2010, Cartography: Visualization of spatial data. Third Edition, New York: Guilford Press.

Kuna J., 2014, Zmiany znaków kartograficznych na $X X$-wiecznych mapach topograficznych $w$ skali 1:100 000 (eng. Symbol changes on 20th century topographic maps in 1:100,000). „Polski Przegląd Kartograficzny" T. 46, nr 1, pp. 47-61 (http://ppk. net.pl/artykuly/2014104.pdf).

Kuna J., 2015a: Metodyczne aspekty analiz przestrzennych GIS wykorzystujących dawne mapy topograficzne. In: A. Czerny, ed., Dawne mapy topograficzne $w$ badaniach geograficzno-histo- 
rycznych. Lublin: Wydawnictwo UMCS, pp. 125-150 (http://phavi.umcs.pl/at/attachments/2016/0708/ 103742-czerny-dawne-mapy-07-07-low-res.pdf).

Kuna J., 2015b, Proste animacje 4D w GIS (eng. Simple 4D animations in GIS). "Acta Universitatis Lodziensis: Folia Geographica Socio-Oeconomica" T.22, pp. 161-169. (http://dx.doi.org/10.18778/15081117.22.09).

Kuncewicz A., 1929, Plany przeglądowe miast polskich (eng. The plans of Polish towns). Sekcja Urbanistyczna Zakładu Architektury Polskiej, Warszawa (http://www.mapywig.org/m_documents/ PL/PLANY_PRZEGLADOWE_MIĀST_POLSKICH_1929_small.pdf).

Lewandowska M., Stelmach M., 1996, Plany miast w polskich archiwach państwowych - katalog. Warszawa: Naczelna Dyrekcja Archiwów Państwowych (http://www.mapywig.org/m_documents/PL/ PLANY_MIAST_W_POLSKICH_ARCHIWACH_ PANSTWOWOYCH_1996.pdf).

Meksuła M.W., 2001, Kartograficzne sposoby prezentowania dynamiki zjawisk (eng. Cartographic presentation methods of dynamic phenomena). „Polski Przegląd Kartograficzny" T. 33, nr 4, pp. 328-338 (http://ppk.net.pl/artykuly/2001402.pdf).

Panecki T., 2014, Problemy kalibracji mapy szczegótowej Polski w skali 1:25 000 Wojskowego Instytutu Geograficznego w Warszawie (eng. Problems with calibration of the detailed map of Poland in 1:25,000 published by the Military Geographical Institute (WIG) in Warsaw). „Polski Przegląd Kar- tograficzny" T. 46, nr 2, pp. 162-172 (http://ppk. net.pl/artykuly/2014203.pdf).

Szady B., 2008, Zastosowanie systemów informacji geograficznej w geografii historycznej. „Polski Przegląd Kartograficzny" T. 40, nr 3, pp. 279-283 (http://ppk.net.pl/artykuly/2008304.pdf).

\section{Internet sources}

http://www.shtetlroutes.eu - the official Shtetl Routes webpage: articles, maps, 3D model teasers and much more.

http://maps.geshergalicia.org/cadastral/pidhaitsi-podhajce-1846/ - interactive cadastral plan of Pidhaitsi (Ukraine)

http://poligonstudio.pl/portfolio/bulb-fiction/ - 3D model teasers

http://igrek.amzp.pl/ - Early maps of Poland and Central Europe

http://www.mapywig.org - Map Archive of Wojskowy Instytut Geograficzny 1919 - 1939

http://teatrnn.pl/przewodniki/strona/71 - the official webpage of "Grodzka Gate - NN Theatre" Centre, section with digital guidebooks

http://www.timesofisrael.com/plans-for-shtetl-routethrough-old-jewish-europe-underway

http://www.haaretz.com/jewish/news/1.568386

\section{Maps}

Kuna J., Kuna A., Majuk E., Tarajko M., 2016, Shtetl Routes. Vestiges of Jewish cultural heritage in cross-border tourism. Tourist map, 1:900,000, Lublin: "Grodzka Gate - NN Theatre" Centre. 